\title{
Comparison of Emotional Intelligence and Mental Toughness of Youth Soccer Players in Terms of Position and Soccer Experience Variables
}

\author{
Atakan YAZICl ${ }^{1}$ (DD), Ahmet YAPAR ${ }^{2}$ (D) , Şenol GÜVEN ${ }^{3}$ \\ Ramazan TAŞÇIOĞLU 4 (D) , ilkay ULUTAŞ ${ }^{5}$ \\ 1 Gazi University, Faculty of Sport Science, ANKARA \\ ${ }^{2}$ Çanakkale Onsekiz Mart University, Faculty of Sport Science, ÇANAKKALE \\ ${ }_{3}^{3}$ Ministry of Education Cumayanı Middle School, AYDIN \\ ${ }^{4}$ Eskişehir Technical University, Faculty of Sport Science, ESKiŞEHIR \\ ${ }^{5}$ Gazi University, Gazi Education Faculty, ANKARA
}

Research Article

DOI: $10.53434 /$ gbesbd.938664

\begin{abstract}
The aim of this research was the comparison of mental toughness (MT) and emotional intelligence (EI) of youth soccer players based on their soccer experience and player positions. Participants of the study composed of totally 458 youth male soccer players who are between $17-20$ years old $(\bar{x}=17,75)$ and 1-14 $(\bar{x}=7,22)$ years of soccer experiences. Data obtained by using demographic questionnaire, Sport Mental Toughness Questionnaire (MTIS), and Trait Emotional Intelligence Questionnaire (TEIQ). According to homogeneity and normality test results, The One-way ANOVA was used for the analysis of data. The findings demonstrated that there is no significant difference between sports age and position variables in terms of MT. In addition, results indicated that soccer experience make differences on well-being and emotionality subscales of TEIQ. Besides, according to player positions and TEIQ subscales, there were significant differences between sociability. In conclusion, soccer experience is one of the factors that influence well-being and emotionality positively. Moreover, it observed that midfield players' social abilities are higher than winger players and defensive midfield players.
\end{abstract}

Keywords: Emotional intelligence, Mental toughness, Soccer, Soccer experience, Player position 


\section{Genç Futbolcuların Duygusal Zekâ ve Zihinsel Dayanıklılık Düzeylerinin Oynadığı Mevki ve Spor Yaşı Değişkenleri Açısından Karşılaștırılması}

$\ddot{O} z$

$\mathrm{Bu}$ araştırmanın amacı genç futbol oyuncularının zihinsel dayanıklılık (ZD) ve duygusal zekâ (DZ) düzeylerinin mevki (oyun pozisyonu) ve spor yașına (az deneyimli-orta deneyimli-deneyimli) bağlı deneyim değişkenleri açısından karşılaştırmaktır. Katılımcılar Türkiye'nin çeşitli kulüplerinde aktif olarak futbol oynayan 17-20 yaş aralığında $(\bar{x}=17,75)$ ve 1-14 spor yaşı aralığında $(\bar{x}=7,22)$ toplam 458 erkek oyuncudan oluşmaktadır. Araştırmanın verileri demografik bilgi formu, Sporda Zihinsel Dayanıklılık Envanteri (SZDE) ile Duygusal Zekâ Özellik Ölçeği (DZÖÖ) uygulanarak elde edilmiştir. Araștırmada elde edilen veriler normallik ve homojenlik varsayımları karşllandığı incelendikten sonra tek yönlü varyans analizi aracılığıyla incelenmiştir. Bulgular, ZD açısından spor yaşı ve sporcu pozisyonu açısından anlamlı farklılık bulunamamışken, DZ açısından spor yaşı değişkeninin iyi olma ve duygusallık boyutları ile sporcu pozisyonu açısından yalnızca sosyallik boyutunda anlamlı bir fark olduğunu göstermiştir. Sonuç olarak spor yaşı arttıkça duygu durum değişkenlerinden iyi olma ve duygusallık pozitif değişim göstermektedir. Ayrıca iletişim becerilerinin sahada da yüksek olması beklenen, orta saha pozisyonundaki oyuncuların diğer pozisyonlara göre daha yüksek sosyal beceriye sahip oldukları araştırmada ortaya çıkan diğer bir sonuçtur.

Anahtar Kelimeler: Duygusal zeka, Zihinsel dayanıklılık, Futbol, Spor yaşı, Oyuncu pozisyonu

\section{Introduction}

In the sports environment, individuals are generally evaluated morphologically, physically, and physiologically. Nevertheless, it should not be forgotten that human beings are living being with social, cultural, and psychological characteristics. Intense emotional reactions such as extreme excitement, anxiety, uncontrolled joy and enthusiasm may begin in a competitive environment where there is intense competition such as winning, becoming a champion, breaking a record, reaching an award, not falling into the lower league or subcategory. These abnormal reactions can have a significant positive or negative impact on motor performance. For this reason, the mental and emotional state of the athlete in the sports environment may produce results closely related to his performance on the field. Lazarus and Folkman (1984) emphasized that the ability to create and maintain appropriate emotional conditions before and during the competition is very important to achieve the desired success in sports and stated that this is the purpose of many mental training programs. Hanin (1997) drew attention to the importance of developing the ability to manage and control emotions for the best possible performance. The definition of performance in sports is made as all of the physiological, biomechanical, and mental processes revealed by the athlete during the competition (Altıntaş \& Akalın, 2008). In addition, psychological skills such as mental toughness, emotional skills, and the ability to feel and manage emotions are stated as mental skills that athletes should have (Cox, 2011). As can be understood from the definitions mentioned above, the place of the psychological state of the athlete in motor performance is important.

Two of the key concepts that affect the psychological state, mental toughness and emotional intelligence have a positive correlation (Yazıcı \& Güçlü, 2019). Sheard (2013) 
defined MT as the ability to control the emotions of the athlete against the stimuli encountered during the match, to maintain his performance and to maintain his selfconfidence. Another researcher emphasized the importance of MT as an important phenomenon that can be effective in the transition of athletes from amateur to professional sports life (Yazıcl, 2019). When examining the studies on demographic characteristics such as age, gender, and income, it was observed that there were significant differences in MT between the positions in which the athletes were in the team (Asamoah \& Grobbelaar, 2016). In addition, a positive relationship was observed between the number of years of doing sports and MT (Horsburgh, Schermer, Veselka \& Vernon, 2009; Nichols, Jones, Polman \& Borkoles, 2009). Sports age is defined as the years that a person has spent on sports throughout his life. The training age is specific to the sports branch and defined as the years that the athlete spends in a certain sports branch (Balyi, Way \& Higss, 2013). Clough, Earle, Perry and Crust (2012) defined MT as a phenomenon that can enable the athlete to be more sociable and social due to the ability of the athlete to remain comfortable, controlled, and calm during the competition. MT appears as the ability to have lower levels of anxiety compared to other athletes in an intensely competitive environment and to transform this into a sportive performance.

According to Salovey and Mayer (1990), emotional intelligence (EI) is the ability to recognize, understand and expressing emotions, understand and analyze others' emotions, and control emotions. It also includes the ability to control the feelings and emotions of the individual and other individuals, to distinguish between these feelings and to use this information to guide the attitudes of the individual. EI is also defined as a subset of social intelligence (Salovey \& Mayer, 1990). In another definition, EI, which is defined as the complement of emotion and intelligence (Ciarrochi, Chan \& Caputi, 2000; Roberts, Zeidner \& Matthews, 2001), consists of some skills that interact with each other (Lopes, Salovey, Côté, Beers \& Petty, 2005).

Various EI-based models are used to explain the relationship between sporting performance and emotions. When these models are examined, it is seen that Salovey and Mayer (1990) are the ability model, Goleman (1995) is the mixed emotional intelligence model, Bar-On (1997) and Petrides (2010) are the perceived emotional intelligence model. Trait EI, proposed by Petrides (2010), focuses on the subjectivity that underlies emotional experience. In this model, EI as a personality trait is defined as a cluster of emotional selfperceptions (Petrides, 2010; Petrides, Pita \& Kokkinaki, 2007). According to Petridesand Furnham (2001), individual well-being, self-control, emotional and sociability skills also constitute the dimensions of EI.

When the literature is examined, it is noteworthy that although there are studies that examine the relationship between MT and EI in different branches (Yazıcl, 2019) and MT and soccer experience (Asamoah \& Grobbelaar, 2016), there is a lack of studies that examine MT and EI in soccer. Therefore, it is important to invesigate MT and EI in soccer as it will contribute to the relevant literature on team sports. This research aims to examine the MT and EI levels of youth soccer players in terms of sports age and game position variables. 


\section{Method}

\section{Participants}

458 soccer players between the ages of 17 and $20(\bar{x}=17.75)$ participated in this study. Participants are youth soccer players who played in Super, $1^{\text {th }}, 2^{\text {nd, }}$ and $3^{\text {trd }}$ leagues during 2018-2019 season in Turkey soccer leagues. Players' soccer experience average is $\bar{x}=7.22$ and 16 of participants (3.5\%) played at least once at the national team level. Based on thier playing positions; $43(9.4 \%)$ of them were goalkeepers, $84(18.3 \%)$ of them were stoppers, $83(18.1 \%)$ of them were fullback, $42(9.2 \%)$ of them were defensive midfield, $68(14.8 \%)$ of them were midfield, 37 (8.1\%) of them were offensive midfield, 63 (13.8) of them were wing, and $38(\%) .8,3)$ of them was determined to be a striker. Distribution of the players displayed in Table 1.

Table 1. Distribution of the participants according to their positions

\begin{tabular}{lcc}
\hline Positions & $\mathbf{N}$ & $\mathbf{\%}$ \\
\hline Goalkeeper & 43 & 9.4 \\
Stoper & 84 & 18.3 \\
Fullback & 83 & 18.1 \\
Defensive midfield & 42 & 9.2 \\
Midfield & 68 & 14.8 \\
Offensive midfield & 37 & 8.1 \\
Wing & 63 & 13.8 \\
Striker & 38 & 8.3 \\
\hline Total & $\mathbf{4 5 8}$ & $\mathbf{1 0 0}$ \\
\hline
\end{tabular}

As the literature was examined, it was seen that Asamoah (2013) divided the players as $4 \times 4$ according to the age-specific to the sports branch. However, in this study, a distinction was made into three groups in order to have a harmonious distribution of moderately experienced and experienced groups. For the inexperienced group, the interval of 4 years is considered and distribution of participants to each training age category displayed in table 2.

Table 2. Participants' sports branch (soccer) specific training age distributions

\begin{tabular}{lcc}
\hline Training Age & N & \% \\
\hline Less experienced (L,1-4 years) & 50 & 10.9 \\
Middle experienced (M, 5-7 years) & 212 & 46.3 \\
Experienced (E, 8 and above) & 196 & 42.8 \\
\hline Total & $\mathbf{4 5 8}$ & $\mathbf{1 0 0}$ \\
\hline
\end{tabular}

\section{Data collection}

Correlational research method was used in this study. The demographic information of the participants was obtained through the demographic information form created by the researchers.

Sport Mental Toughness Questionnaire (SMTQ): To measure mental toughness, the Turkish version of Mental Toughness Inventory in Sports (Sheard, Golby \& van Wersch, 2009) was used. The Turkish version of the inventory was conducted by Altıntaş and Koruç 
(2016). The inventory consists of 14 items and 3 sub-dimensions (control, confidence, and constancy sub-dimensions) with a 4-point Likert scale.

Trait Emotional Intelligence Questionnaire (TEIQe): Emotional intelligence measurements were made with the Emotional Intelligence Trait Scale, originally named Trait Emotional Intelligence Questionnaire (TEIQ), which was developed based on the perceived (trait) emotional intelligence model of Petrides (2009) and adapted into Turkish by Ulutaş (2017). The questionnaire was composed of a 7-point Likert structure, TEIQ consists of 30 items and has 4 sub-dimensions: well-being, self-control, emotionality, and sociability.

Ethics Approval

The research protocol was approved by the Gazi University Ethical Commision (Protocol No: 2021-273).

\section{Statistical Analysis}

After homogeneity and normality assumptions were met, One-way analysis of variance (ANOVA) was performed to compare the SMTQ and TEIQe sub-dimension scores of the data in terms of soccer experience and position variables. For Post-Hoc comparisons, the Tukey test was used to determine which groups had significant differences. The significance level was determined as $\mathrm{p}<.05$ for the comparisons.

\section{Results}

\section{Sports Age and Mental Toughness ANOVA Findings}

The results of the analysis One-way analysis of variance comparing the MTIS sub-scale scores of the participants showed that there is no statistically significant difference between the categories of subsclaes of MTIS. The scores of each subscales were observed for Confidence sub-dimension ( $p=.205>.05)$, for constancy sub-dimension $(p=.130>.05)$ and for control sub-dimension ( $p=.069>.05)$. The mean scores of the subscales were above the avarege and closed to each other. The Sports Age and Mental Toughness One Way ANOVA results are displayed in table 3.

Table 3. Sports age and mental toughness ANOVA findings

\begin{tabular}{|c|c|c|c|c|c|c|c|c|c|c|}
\hline & & $\mathbf{N}$ & & Sd & & df & SS & MS & $\mathbf{F}$ & $\mathbf{p}$ \\
\hline & $\mathrm{L}$ & 50 & 3,17 & ,468 & Intergroup & 2 & 856 & ,428 & 1,59 & ,205 \\
\hline \multirow[t]{3}{*}{ Confidence } & M & 212 & 3,26 & ,507 & Withingroups & 455 & 122,6 & 270 & & \\
\hline & $\mathrm{E}$ & 196 & 3,31 & ,543 & Total & 457 & 123,5 & & & \\
\hline & $\mathrm{L}$ & 50 & 3,45 & ,569 & Intergroup & 2 & 1,193 & ,597 & 2,05 & 130 \\
\hline \multirow[t]{3}{*}{ Constancy } & M & 212 & 3,38 & ,585 & Withingroups & 455 & 132,6 & 291 & & \\
\hline & $\mathrm{E}$ & 196 & 3,48 & ,477 & Total & 457 & 133,8 & & & \\
\hline & $\mathrm{L}$ & 50 & 1,98 & ,599 & Intergroup & 2 & 1,193 & ,597 & 2,68 & 069 \\
\hline \multirow[t]{2}{*}{ Control } & M & 212 & 2,19 & 688 & Withingroups & 455 & 132,6 & 291 & & \\
\hline & $\mathrm{E}$ & 196 & 2,08 & ,679 & Total & 457 & 133,8 & & & \\
\hline
\end{tabular}

L: Less experienced, M: Middle experienced, E: Experienced* ${ }^{*}<.05$ 


\section{Sports Age and Emotional Intelligence ANOVA Findings}

The One Way ANOVA was conducted to examine the each TEIQsubscale scores and participants' soccer experience categories. Results showed a significant difference were observed between sports age groups for the well-being subscale $(F(2,455)=7.723, \mathrm{p}=.001$ $<.05)$ and emotionality subscale $(F(2,455)=4.199, p=.016<.05)$.

For Well-being subscale, Tukey Post-Hoc test was conducted to determine which groups differ from each other among age groups. According to the Tukey results, lessexperienced youth soccer players group $(\bar{x}=4.99, S d=1.05)$ statistically differ from middle experienced $(\bar{x}=5.36, S d=.91)$ and Experienced $(\bar{x}=5.55, S d=.91)$ groups.

For Emotionality subscale, Tukey Post-Hoc test was conducted to determine which groups differ from each other among age groups. According to the Tukey results, the Experienced youth soccer players group $(\bar{x}=5.54, S d=.77)$ have statistically higher score than less-experienced $(\bar{x}=5.23, S d=.76)$ and middle experienced $(\bar{x}=5.34, S d=.95)$ groups. The Sports Age and Emotional Intelligence ANOVA findings are displayed in table 4.

Table 4. Sports age and emotional intelligence ANOVA findings

\begin{tabular}{|c|c|c|c|c|c|c|c|c|c|c|}
\hline & & $\mathbf{N}$ & & Sd & & df & SS & MS & $\mathbf{F}$ & $\mathbf{p}$ \\
\hline & $\mathrm{L}$ & 50 & 4,99 & 1,05 & Intergroup & 2 & 13,29 & 6,65 & 7,72 & ,001* \\
\hline \multirow[t]{3}{*}{ Well-being } & M & 212 & 5,36 & 91 & Withingroups & 455 & 391,7 & ,86 & & \\
\hline & $\mathrm{E}$ & 196 & 5,55 & 91 & Total & 457 & 405,0 & & & \\
\hline & $\mathrm{L}$ & 50 & 5,12 & 93 & Intergroup & 2 & 122 & 06 & ,058 & ,943 \\
\hline \multirow[t]{3}{*}{ Self control } & $\mathrm{M}$ & 212 & 5,15 & 1,10 & Withingroups & 455 & 476,7 & 1,04 & & \\
\hline & $\mathrm{E}$ & 196 & 5,12 & ,95 & Total & 457 & 476,8 & & & \\
\hline & $\mathrm{L}$ & 50 & 5,23 & ,76 & Intergroup & 2 & 6,194 & 3,09 & 4,02 & ,016* \\
\hline \multirow[t]{3}{*}{ Emotionality } & M & 212 & 5,34 & ,95 & Withingroups & 455 & 335,6 & 738 & & \\
\hline & $\mathrm{E}$ & 196 & 5,54 & ,77 & Total & 457 & 4,33 & & & \\
\hline & $\mathrm{L}$ & 50 & 4,86 & 85 & Intergroup & 2 & 470,3 & 2,16 & 2,10 & 124 \\
\hline \multirow[t]{2}{*}{ Sociability } & M & 212 & 4,93 & 1,01 & Withingroups & 455 & 474,6 & 1,03 & & \\
\hline & $\mathrm{E}$ & 196 & 5,11 & 1,05 & Total & 457 & 4,33 & & & \\
\hline
\end{tabular}

L: Less experienced, M: Middle experienced, E: Experienced, ${ }^{*} \mathrm{p}<.05$

\section{Position and Mental Toughness ANOVA Findings}

One-way analysis of variance was conducted to compare the MTIS sub-scale scores of the participants according to the position played. Analysis findings showed that there is no statistical difference between the scores of all sub-dimensions of the MTIS according to the positions. 
Table 5. Position and mental toughness ANOVA findings

\begin{tabular}{|c|c|c|c|c|c|c|c|c|c|c|}
\hline & & $\mathbf{N}$ & & Sd & & df & SS & MS & $\mathbf{F}$ & $\mathbf{p}$ \\
\hline \multirow[t]{8}{*}{ Confidence } & G & 43 & 3,27 & ,515 & Intergroup & 7 & 1,021 & ,146 & ,536 & ,807 \\
\hline & S & 84 & 3,33 &, 502 & Withingroups & 450 & 122,5 & ,272 & & \\
\hline & $\mathrm{F}$ & 83 & 3,23 & 603 & Total & 457 & 123,5 & & & \\
\hline & DM & 42 & 3,24 & ,467 & & & & & & \\
\hline & M & 68 & 3,25 &, 555 & & & & & & \\
\hline & $\mathrm{OM}$ & 37 & 3,36 & ,528 & & & & & & \\
\hline & $\mathrm{W}$ & 63 & 3,27 & ,478 & & & & & & \\
\hline & S & 38 & 3,19 & ,425 & & & & & & \\
\hline \multirow[t]{8}{*}{ Constancy } & G & 43 & 3,47 & ,519 & Intergroup & 7 & 2,252 & 322 & 1,10 & 361 \\
\hline & S & 84 & 3,55 &, 554 & Withingroups & 450 & 131,5 & ,292 & & \\
\hline & $\mathrm{F}$ & 83 & 3,42 &, 511 & Total & 457 & 133,8 & & & \\
\hline & DM & 42 & 3,32 &, 513 & & & & & & \\
\hline & M & 68 & 3,35 & ,589 & & & & & & \\
\hline & $\mathrm{OM}$ & 37 & 3,41 & ,583 & & & & & & \\
\hline & $\mathrm{W}$ & 63 & 3,33 &, 559 & & & & & & \\
\hline & S & 38 & 3,40 & ,448 & & & & & & \\
\hline \multirow[t]{7}{*}{ Control } & G & 43 & 2,13 & 686 & Intergroup & 7 & 2,145 & ,306 & 664 & ,703 \\
\hline & S & 84 & 2,20 & 696 & Withingroups & 450 & 207,8 & ,462 & & \\
\hline & $\mathrm{F}$ & 83 & 2,18 & ,769 & Total & 457 & 209,9 & & & \\
\hline & DM & 42 & 2,11 & ,584 & & & & & & \\
\hline & $\begin{array}{c}\mathrm{M} \\
\mathrm{OM}\end{array}$ & $\begin{array}{l}68 \\
37\end{array}$ & $\begin{array}{l}2,08 \\
2,14\end{array}$ & $\begin{array}{l}, 708 \\
, 544\end{array}$ & & & & & & \\
\hline & W & 63 & 2,07 & 666 & & & & & & \\
\hline & S & 38 & 1,96 & ,599 & & & & & & \\
\hline
\end{tabular}

G:Goalkeeper, S:Stoper, F:Fullback, DM:Defensive midfield, M:Midfield, OM:Offensive Midfield, W:Wing, ST:Striker, ${ }^{*} \mathrm{p}<.05$

\section{Emotional Intelligence ANOVA Findings with Position}

The One-Way ANOVA was conducted to examine the TEIQ sub-scale scores of the participants in terms of their playing positions. The analysis findings showed that only a statistically significant difference was observed in the sociability $[\mathrm{F}(7,450)=2.796$, $\mathrm{p}=$ $.007<.05]$ sub-scale of the TEIQ in terms of the positions the participants played. Post-hoc Tukey analysis was conducted in order to examine in which position the responses given by the athletes to the sub-dimension of sociability differ from each other.

According to the analysis results, the average score given by the midfielders $(\bar{x}=5.29$, $\mathrm{SS}=.872)$ in the sociability sub-dimension was higher than the average score given by the wing $(\bar{x}=4.74, S S=1.055)$ and defensive midfield $(\bar{x}=4.68, S S=1.204)$ players. It was observed to be high. 
Table 6. Emotional intelligence ANOVA findings with position

\begin{tabular}{|c|c|c|c|c|c|c|c|c|c|c|}
\hline & & $\mathbf{N}$ & & Sd & & df & SS & MS & $\mathbf{F}$ & $\mathbf{p}$ \\
\hline \multirow[t]{8}{*}{ Well-being } & G & 43 & 5,55 & ,938 & Intergroup & 7 & 5,599 & ,80 & 901 &, 505 \\
\hline & S & 84 & 5,32 & 882 & Withingroups & 450 & 399,5 & ,88 & & \\
\hline & $\mathrm{F}$ & 83 & 5,23 & 1,01 & Total & 457 & 405,0 & & & \\
\hline & DM & 42 & 5,42 & 719 & & & & & & \\
\hline & M & 68 & 5,47 & 981 & & & & & & \\
\hline & $\mathrm{OM}$ & 37 & 5,41 & ,857 & & & & & & \\
\hline & W & 63 & 5,54 & 987 & & & & & & \\
\hline & S & 38 & 5,41 & 1,06 & & & & & & \\
\hline \multirow[t]{8}{*}{ Self-control } & $\bar{G}$ & 43 & 5,26 & 1,16 & Intergroup & 7 & 6,86 & ,98 & ,940 & , 475 \\
\hline & S & 84 & 5,13 & 1,10 & Withingroups & 450 & 469,9 & 1,04 & & \\
\hline & $\mathrm{F}$ & 83 & 5,11 & 1,05 & Total & 457 & 476,8 & & & \\
\hline & DM & 42 & 4,99 & ,946 & & & & & & \\
\hline & M & 68 & 5,19 & ,959 & & & & & & \\
\hline & $\mathrm{OM}$ & 37 & 5,22 & ,823 & & & & & & \\
\hline & $\mathrm{W}$ & 63 & 5,27 & 1,01 & & & & & & \\
\hline & S & 38 & 4,83 & 951 & & & & & & \\
\hline \multirow[t]{8}{*}{ Emotionality } & G & 43 & 5,46 & ,991 & Intergroup & 7 & 5,20 & ,74 & ,993 & ,435 \\
\hline & S & 84 & 5,36 & 912 & Withingroups & 450 & 336,6 & ,74 & & \\
\hline & $\mathrm{F}$ & 83 & 5,41 & ,926 & Total & 457 & 341,8 & & & \\
\hline & DM & 42 & 5,20 & 825 & & & & & & \\
\hline & M & 68 & 5,62 & ,826 & & & & & & \\
\hline & $\mathrm{OM}$ & 37 & 5,40 & 696 & & & & & & \\
\hline & $\mathrm{W}$ & 63 & 5,39 & 909 & & & & & & \\
\hline & $\mathrm{S}$ & 38 & 5,41 & 611 & & & & & & \\
\hline \multirow[t]{8}{*}{ Sociability } & G & 43 & 5,41 & 894 & Intergroup & 7 & 19,78 & 2,82 & 2,80 &, $00^{*}$ \\
\hline & $S$ & 84 & 4,99 & 993 & Withingroups & 450 & 454,8 & 1,01 & & \\
\hline & $\mathrm{F}$ & 83 & 4,85 & 1,05 & Total & 457 & 474,6 & & & \\
\hline & DM & 42 & 4,68 & 1,20 & & & & & & \\
\hline & $\mathrm{M}$ & 68 & 5,29 & ,872 & & & & & & \\
\hline & $\mathrm{OM}$ & 37 & 5,06 & 1,05 & & & & & & \\
\hline & W & 63 & 4,74 & 1,05 & & & & & & \\
\hline & S & 38 & 5,17 & 883 & & & & & & \\
\hline
\end{tabular}

G:Goalkeeper, S:Stoper, F:Fullback, DM:Defensive midfield, M:Midfield, OM:Offensive Midfield, W:Wing, ST:Striker, *p<.05

\section{Discussion and conclusion}

The aims of this study examine the MT and EI levels of youth soccer players in terms of sport age and game position variables. When the researches in the field of sports psychology were examined, it was observed that Gucciardi and Gordon (2009) stated that it is a concept for MT that can be affected by different variables. When the literature is examined, the relationship between MT and success (Nichols, Jones, Polman \& Borkoles, 2009), intercultural impact (Yazıcı \& Güçlü, 2019), gender influence (Masum, 2014), psychological skills (Gill, Lane, Thelwell \& Devonport, 2011), and interaction with sports type (Nichols, Jones, Polman \& Borkoles, 2009) and the effects of personal performance improvement studies (Yazıcı, Savaş \& Günay, 2018) have been investigated. Horsburgh, Schermer, Veselka, and Vernon, (2009) stated that MT may change according to the year of doing sports and can be associated with some personality types. Nichols, Jones, Polman, and Borkoles (2009) emphasized that MT increased in terms of struggle, control and commitment, which are sub-dimensions of MT, compared to the year of doing sports. However, the results obtained from this study do not differ as clearly as the results of the studies conducted by Nichools, Jones, Polman, and Borkoles (2009) and Horsburgh, 
Schermer, Veselka, and Vernon (2009). According to the findings obtained from the research, no statistically significant difference was observed between the years of doing sports and MT levels, but it is seen that the average of the sub-dimension scores obtained from the MT inventory increases as the years of doing sports increase. According to Cox (2011), MT is one of the psychological phenomena that should be in performance athletes and it is a skill that can be developed and where positive psychological approach plays a fundamental role.

When Table 4 is examined, it is observed that there is a constancy increase between the well-being and emotionality sub-dimensions of EI and the age specific to the sport branch (depending on the training age). It can be said that besides being a feature that characterizes self-confidence, the well-being sub-dimension includes understanding the emotions of other individuals and empathy skills in the emotional dimension (Petrides \& Furnham, 2001). Therefore, the well-being and emotionality sub-dimensions of the participants' EI sub-dimensions gradually improved depending on the age of training. Emotional skills, such as understanding or evaluating emotions, develop with age, experience, and learning, just like numerical and verbal abilities. Bar-On (1997), who developed one of the most valid theoretical model and measurement tools related to the concept of EI, reported that EI develops with age. Derksen, Kramer, and Katzko (2002) suggested that scores obtained from EI tests increase with age. In addition, according to Petrides and Furnham (2001), the emotionality dimension consists of components such as the participants' ability to affect the feelings of other individuals, being determined, adapting to new conditions, and self-motivation. It can be said that these components are among the skills that increase with experience. Considering that the increase in the training age means the increase in the experience, this result (Table 4), which appears especially in the EI model, is an expected situation due to the relationship of EI with personality.

In Table 5, MT levels of soccer players are compared according to their positions. Findings obtained from the research results revealed that there is no significant difference between the positions of the players and their MT levels. When the literature was examined, it was observed that MT scores of athletes working in the midfield were higher than other players in the study by Asamoah (2013), in which MT levels were investigated according to the positions played in soccer. However, the findings obtained from this study show that there is no similar difference for this study. From this point of view, it is thought that one of the reasons for the lack of a significant difference between positions is due to the high MT scores of all the participants in the study. In addition, according to Yazıcı, Savaş, and Günay (2018), a positive MT development is expected at the end of personal performance studies planned for basketball players according to the positions of the athletes.

Within the scope of the study, it was examined whether the EI skills of the participants differed according to the positions they played (Table 6) and it was observed that the players in the midfield had higher social skill scores than the athletes who played in other positions. Midfielders provide the link between offense and defense. During the defense, the midfield players increase the pressure on the opponent and narrow the field, while they 
carry the technical features that create free space for the strikers and prepare the position during the attack (Asamoah, 2013). In addition, tasks such as setting up a game, directing the game, making quick decisions, controlling the positions of teammates on the defense and offensive line and providing the necessary communication during the match are among the tasks that midfielders should frequently do in soccer. Therefore, midfield players in soccer are the people who provide the most communication and coordination compared to the players in other positions. Therefore, it can be expected that players serving in the midfield will have higher EI scores compared to athletes in other positions. Asamoah (2013) stated that the players serving in the midfield have higher skills compared to the wing and defensive positions, as they have both offensive and defensive functions. EI consists of four main skills (Bar-On, Handley \& Fund, 2005; Mayer, Caruso \& Salovey, 1999; Mayer, Salovey \& Caruso, 2004; Lopes, Salovey, Côté, Beers \& Petty, 2005) and one of these skills is to be able to use emotions, It is known to involve focusing the attention, thinking logically, and generating, using and feeling emotions for correct communication. It is very important for this sub-skill of EI to be able to realize the effect of emotions on mental processes such as problem solving, creativity and comm unication. In addition, this sub-skill plays an important role especially on decision-making processes and strategies. Therefore, it can be expected that the EI levels of the midfield players who direct their teammates during the competition, determine the strategy according to their position on the field or shape the game, and who are in constant communication with their friends while doing these, will be higher than the players working in other positions.

According to results there was no difference between the experience levels and positions of young soccer players in terms of MT; some differences were found in terms of EI. Although, The English Football Association (FA) (2019) stated that social skills are one of the features that should be present in youth soccer players and are also indispensable to be developed. Therefore, it is thought that the results obtained from this study will help the coaches working with youth soccer players to understand the relationship between the concepts of MT and EI and the sports-specific training ages and the positions they play. In addition, according to Gucciardi and Mallett (2010) coaches are responsible of develop athletes psychological skill such as MT. But, coaches has to improve and develop their self to knowledge about to how to improve athletes psychological skills. Therefore, sports psychologists can help to coaches understanding to MT and EI environment in sport.

\title{
Author note
}

This study was presented as an oral presentation at the $17^{\text {th }}$ International Sports Sciences Congress 13-16 November 2019 in Antalya, Turkey.

\author{
Corresponding Address: \\ Research Assistant Atakan YAZICI \\ Gazi University, Faculty of Sport Sciences \\ Emniyet Mah., Abant 1 Cd. 10/1C, 06210 Yenimahalle/ANKARA \\ ORCID: https://orcid.org/0000-0001-8899-2515 \\ atakanyazici@gazi.edu.tr
}




\section{References}

1. Altıntaş, A., \& Akalan, C. (2008). Mental training and high performance. SPORMETRE Beden Eğitimi ve Spor Bilimleri Dergisi, 6(1), 39-43.

2. Altıntaş, A., \& Koruç, P. B. (2016). Examining psychometric properties of the sport mental toughness questionnaire-SMTQ. Hacettepe Journal of Sport Sciences. 27(4), 163-171.

3. Asamoah, B. (2013). The role of mental toughness, psychological skills and team cohesion in soccer performance (Doctoral Dissertation). Stellenbosch, Stellenbosch University.

4. Asamoah, B., \& Grobbelaar, H. (2016). Positional comparisons of mental toughness, psychological skills and group cohesion among soccer players. African Journal for Physical Activity and Health Sciences, 22(3:1), 747-759.

5. Balyi, I., Way, R., \& Higgs, C. (2013). Long-term athlete development. New York: Human Kinetics.

6. Bar-On, R. (1997). Bar-On emotional quotient inventory (EQ-I): Technical Manual. Toronto, Canada: InMulti-HealthSystems.

7. Bar-On, R., Handley, R. \& Fund, S. (2005). The impact of emotional intelligence on performance. In Druskat, V., Sala, F. \& Mount, G. (Eds.) Linking emotional intelligence and performance at work: Current research evidence (pp.3-19).

8. Ciarrochi, J. V., Chan, A. Y. C., \& Caputi, P. (2000). A critical evaluation of the emotional intelligence construct. Personality and Individual Differences, 28(3), 539-561.

9. Clough, P., Earle, K., Perry, J. L., \& Crust, L. (2012). Comment on "Progressing measurement in mental toughness: A case example of the Mental Toughness Questionnaire 48" by Gucciardi, Hanton, and Mallett (2012). Sport, exercise, and performance psychology, 1(4), 283-287.

10. Cox, R. H. (2011). Sport psychology: Concepts and applications (7th ed.). New York: McGrawHill Education.

11. Derksen, J., Kramer I., \& Katzko, M. (2002). Does a self-report measure for emotional intelligence assess something different than general intelligence? Personality and Individual Differences, 32, 37-48.

12. Gill, G. S., Lane, A. M., Thelwell, R. \& Devonport, T. (2011). Relationship between emotional intelligence and psychological skills. Indian Journal of Fitness, 7, 9-16.

13. Goleman, D. (1995). Emotional intelligence (Why it can mattermorethan IQ). New York: Bantam Dell.

14. Gucciardi, D. F., \& Mallett, C. J. (2010). Mental toughness. In Routledge handbook of applied sport psychology (pp. 551). London: Routledge.

15. Gucciardi, D., \& Gordon, S. (2009). Development and preliminary validation of the cricket mental toughness inventory (CMTI). Journal of Sports Science, 27(12), 1293-1310.

16. Hanin, Y. L. (1997). Emotions and athletic performance. Individual zones of optimal functioning model. European Yearbook of Sport Psychology, 1, 29-72.

17. Horsburgh, V. A., Schermer, J. A., Veselka, L., \& Vernon, P. A. (2009). A behavioural genetic study of mental toughness and personality. Personality and individual differences, 46(2), 100105.

18. Lazarus, R. S., \& Folkman. S. (1984). Stress, appraisal and coping. New York: Springer.

19. Lopes, P. N., Salovey, P., Côté, S., Beers, M., \& Petty, R. E. (2005). Emotion regulation abilities and the quality of social interaction. Emotion, 5(1), 113.

20. Masum, R. (2014). A mixed-method analysis of mental toughness in elite and sub-elite male and female tennis players in Pakistan. Advances in Social Sciences Research Journal, 1,110-122.

21. Mayer, J. D., Caruso, D. R., \& Salovey, P. (1999). Emotional intelligence meets traditional standarts for an intelligence. Intelligence, 27(4), 267-298. 
22. Mayer, J. D., Salovey, P., \& Caruso, D. R. (2004). Emotional Intelligence: Theory, findings and implications. Psychological Inquiry, 15(3), 197-215.

23. Nicholls, A. R., Jones, C. R., Polman, R. C. J., \& Borkoles, E. (2009). Acutesport-related stressors, coping, and emotion among professional rugby union players during training and matches. Scandinavian Journal of Medicine and Science in Sports, 19(1), 113-120.

24. Petrides, K, V. (2009). Technical manual for the trait emotional intelligence questionnaires (TEIQUe). London, England: London Psychometric Laboratory.

25. Petrides, K, V. (2010). Trait emotional intelligence theory. Industrial and Organizational Psychology, 3(2), 136-139.

26. Petrides, K, V., \& Furnham, A. (2001). Trait emotional intelligence: Psychometric investigation with reference to established trait taxonomies. European Journal of Personality, 15(6), 425-448.

27. Petrides, K, V., Pita, R., \& Kokkinaki, F. (2007). The location of trait emotional intelligence in personality factor space. British Journal of Psychology, 98(2), 273-289.

28. Roberts, R. D., Zeidner, M., \& Matthews, G. (2001). Does emotional intelligence meet traditional standards for an intelligence? Some new data and conclusions. Emotions. 1(3), 196231.

29. Salovey, P., \& Mayer, J. D. (1990). Emotional intelligence. Imagination, Cognition, and Personality, 9(3), 185-211.

30. Sheard, M. (2013). Mental toughness: The mindset behind sporting achievement ( $2^{\text {nd }}$ ed.). New York: Routledge.

31. Sheard, M., Golby, J., \& Van Wersch, A. (2009). Progress toward construct validation of the Sports Mental Toughness Questionnaire (SMTQ). European Journal of Psychological Assessment, 25(3), 184-191.

32. The FA. (n.d.). FA Philophy. Retrieved from The Future England Player Skills and Attributes website: http://www.thefa.com/learning/england-dna/the-future-englandplayer/attributes-and-skills

33. Ulutaş, İ. (2017). Psychrometric properties of the trait emotional intelligence questionnaire (TEIQe) in Turkish. Current Psychology, 38(3), 775-781.

34. Yazıcı, A. (2019). Kavramsal bakış açısı ile sporda üstün başarı için zihinsel dayanıklılık. In N. Dal (Ed.), Spor Psikolojisinde Yeni Yaklaşımlar (pp. 75-97). Ankara: Akademisyen Kitabevi.

35. Yazıcı, A., \& Güçlü, M. (2019). Psikolojik performans farklılıkları açısından profesyonel basketbol: profesyonel basketbol oyuncularında zihinsel dayanıklılık ve duygusal zekânın çeşitli değişkenler açısından incelenmesi. Mauritus: LAP LAMBERT Academic Publishing. ISBN:978613-9-99198-3

36. Yazıcı, A., Savaş, S., \& Günay, M. (2018, April). The effect of implementation of a 6-week basketball-specific aerobic training on mental toughness and anxiety variables. Presented proceeding at IV International Exerciseand Sport Psychology Congress, Association of Exercise and Sport Psychology, İstanbul. 